\title{
Walls of silence and organized crime: a theoretical and empirical exploration into the shielding of criminal activities from authorities
}

\author{
Robert A. Roks ${ }^{1} \cdot$ Edwin W. Kruisbergen $^{2} \cdot$ Edward R. Kleemans $^{3}$
}

\begin{abstract}
In this article, we aim to further our understanding of the social embeddedness of organized crime by exploring the (possible) ways the social environment adds to the shielding of organized crime or criminal activities by organized crime groups. We argue that the metaphor of 'walls of silence' provides a fruitful way to examine the shielding of organized crime. Based on a theoretical and empirical exploration of 30 cases from the fifth data sweep of Dutch Organized Crime Monitor, we illustrate how organized crime offenders in the Netherlands depend on the silence and secrecy of co-offenders, victims, bystanders, and others who are aware of their (criminal) activities. Furthermore, we present a framework of the shielding of organized crime activities to provide insight into how offenders not only make use of the social environment to shield their activities, but also how the social environment can (purposely) act as walls of silence and secrecy.
\end{abstract}

Keywords Organized crime $\cdot$ Social embeddedness $\cdot$ Secret societies $\cdot$ Shielding $\cdot$ Walls of Silence

\section{Introduction}

According to Paoli and Vander Beken (2014), organized crime is considered a contested concept: the definition and conceptualization of organized crime do not only differ between the United States and European countries, but the meaning, territorial

Robert A. Roks

roks@law.eur.nl

1 Department of Criminology, Erasmus School of Law, Erasmus University Rotterdam, Rotterdam, The Netherlands

2 Ministry of Justice and Security, Hague, The Netherlands

3 Serious and Organized Crime and Criminal Justice, Vrije Universiteit Amsterdam, Amsterdam, The Netherlands 
scope, and legitimacy of organized crime also change over time within specific countries. In research on organized crime in the Netherlands, the prevailing definition considers groups to be organized crime groups if they are focused primarily on obtaining illegal profits, if they systematically commit crimes that cause serious damage to society, and if they are fairly competent in shielding their criminal activities from authorities (Fijnaut et al. 1998: 26-27; Kleemans 2007: 180). The last characteristic, the capability of organized crime groups to shield their activities from authorities, may occur through various strategies, including "corruption, violence, intimidation, storefronts, communication in codes, counter surveillance, media manipulation, and the use of experts such as notaries public, lawyers, and accountants" (Kleemans 2007: 180).

Although organized crime groups are "often portrayed as entities that derive their strength from strong internal cohesion and an ability to conceal their illegal activities from the outside world", Van de Bunt et al (2014: 321) identify a variety of interfaces between organized crime and the legitimate world that "are by no means necessarily antagonistic or aimed at avoiding one another". In fact, research suggests that organized crime has "a habit of interacting with its social environment" (Van de Bunt et al. 2014: 321). Furthermore, the social environment can play a pivotal part in the concealment and shielding of organized crime (Kleemans et al. 1998; 2002; Kleemans \& Van de Bunt 1999; Van de Bunt et al 2014). Various studies have documented that organized crime "does not exist in a social vacuum" (Van de Bunt et al 2014: 321) and that broader social structures can operate as a "silent shell surrounding criminal networks" (Jaspers 2020: 59).

In this article, we aim to further our understanding of the social embeddedness of organized crime by exploring the (possible) ways the social environment adds to the shielding of organized crime or criminal activities by organized crime groups. Specifically, we build on the notion of 'walls of silence' put forward by Van de Bunt (2007; 2010). In his analysis, Van de Bunt (2010) explored how major frauds remained hidden from the larger social environment, and particularly victims, bystanders, and supervising agencies. In cases of major frauds, Van de Bunt argues that "the problem extends beyond failing supervision to the successful concealment of illegal activities by the perpetrators and the silence maintained within their social environments" (Van de Bunt, 2010: 436). We argue that the relevance of these insights goes beyond the study of corporate crime and that the metaphor of "walls of silence' provides a fruitful way to examine the shielding of organized crime. Based on a theoretical and empirical exploration of 30 cases from the fifth data sweep of the Dutch Organized Crime Monitor, we will illustrate how organized crime offenders in the Netherlands depend on the silence and secrecy of co-offenders, victims, bystanders, and others who are aware of their (criminal) activities. Furthermore, we present a framework of the shielding of organized crime activities to provide insight into how offenders not only make use of the social environment to shield their activities but also how the social environment can (purposely) act as walls of silence and secrecy.

This article proceeds as follows. First, we provide a brief overview of the literature on the social embeddedness of organized crime and how this relates to the shielding of organized crime. Second, we outline the methodology and the organized 
crime cases that were analyzed. Third, we present our main results, focusing on the ways the social environment plays a role in the shielding and concealment of organized crime. These empirical examples of the shielding of organized crime result in a framework of the shielding of organized crime that we elaborate upon in our conclusion.

\section{'Walls of silence' and the social embeddedness of organized crime}

Fielding (2017: 16) notes that "secrecy amongst participants is widely regarded as a hallmark of organized crime". According to Van de Bunt (2010: 438), the effectiveness of secrecy seems "to be strongly dependent on the extent to which perpetrators can shield their activities from the world outside". In general, the central point of departure in research on the shielding of organized crime activities can be summarized as "the greater the isolation, the greater the chance that secrets will be kept" (Van de Bunt 2010: 438; cf. Van de Bunt 2007: 115-116; 2010: 438; Siegel 2011: 110; Jaspers 2020: 57). This is exemplified by Simmel's (1906) notion of secret societies, in which secrecy and trust are maintained by ways of internal dynamics, secretive and selective communication (Gambetta 2009), a culture of silence (Siegel 2011), strong ties amongst members and isolation from other groups andto some extent - the broader society (Van de Bunt 2010: 438; Fijnaut \& Paoli 2004: 239-262; 603-621). Research into Italian Mafia groups, such as the Cosa Nostra and 'Ndrangheta, and other 'Mafias', such as Chinese triads, Japanese yakuza, and more recent criminal syndicates (Catino 2020; Paoli 2020; Reuter \& Paoli 2020; Varese 2020) also shows how internal cohesion and secrecy are not only important for the concealment of criminal activities but also for the continuity of these organized crime groups.

Although the concept of secret societies has been ascribed to various organized crime groups, total isolation and secrecy might be overstating the empirical reality of organized crime and the criminal activities of organized crime groups (cf. Van de Bunt 2007: 115-116). Zaitch (2005: 213), for instance, signals the ambiguity of secrecy in his research on Colombian drugs entrepreneurs, noting that "secrecy is a social resource, an adaptive device to conceal information" but that secrecy can also hinder the drugs business. Paoli (2003) also highlights how the strength of traditional Sicilian Mafia groups functioned as a serious handicap getting involved in international drug trafficking. These observations relate to debates about the efficiency/security trade-off in criminal networks. Inspired by a paper by Krebs (2002) on terrorist networks, Morselli et al (2007) argue that criminal networks also face a trade-off between efficiency (and the free flow of information between all actors, which is important to reach specific goals) and security (which calls for secrecy).

As Van de Bunt et al. (104: 321) argue, organized crime has "a habit of interacting with its social environment". In criminology, the concept of social embeddedness is used to examine how organized crime interacts with and depends on its local and social surroundings. Following the seminal work by Granovetter (1985) and social network theorists, various organized crime researchers have explored the relational and structural aspects of the embeddedness of organized crime (e.g., 
Natarajan 2006; Morselli 2009; Carrington 2011; Campana 2011; Varese 2011; Bouchard \& Morselli 2014; Bouchard 2020; Bright \& Whelan 2020).

To date, the majority of studies on the social embeddedness of organized crime have focused on relational aspects of embeddedness, signaling that "criminal activities cannot be separated from the social relations between the participants and the institutional environments in which their interactions take place" (Van de Bunt et al 2014: 323). For instance, various reports of the Dutch Organized Crime Monitor (Kleemans et al 1998; Kleemans et al 2002; Van de Bunt \& Kleemans 2007; Kruisbergen et al. 2012) have documented how criminal collaborations seem to adhere to the laws of both geographical and social proximity (Kleemans and Van de Bunt 1999; Kleemans \& De Poot 2008; Van de Bunt et al. 2014); a finding that is also mirrored in research on the origin and growth of (organized) cybercrime networks (Leukfeldt et al. 2017, 2019), as well as in research on the choices offenders make when they invest their money in the legal economy (Kruisbergen et al., 2015). In sum, the relational dimension of the social embeddedness of organized crime promotes trust amongst co-offenders and facilitates the shielding of organized crime from the authorities.

Since existing social ties are not always able to bridge 'structural holes' (Burt 1992) between countries, different ethnic groups, or between the licit and illicit world (Leukfeldt et al. 2019: 328), the structural side of social embeddedness is also relevant in the context of organized crime. This refers to the importance of "branches of industry, occupations, communities or places" (Van de Bunt et al 2014: 323-324). Concerning the role of occupations, this structural side of embeddedness is not contingent upon the occupations as such but rather determined by the intersections with legitimate activities (Van de Bunt et al 2014: 328). Kleemans and Van de Bunt (2008: 193-195) illustrate how occupations, work relations, and work settings provide not only opportunities for organized crime activities but also to gain trust. Furthermore, "the blending of work relations and social relations may also contribute to the.effective concealment of illegal activities" (Kleemans and Van de Bunt 2008: 196). This element of concealment is also shown in other studies documenting the structural embeddedness of organized crime (for an overview, see e.g., Savona et al 2017; Kleemans \& Van Koppen, 2020; Van Koppen et al 2020). In their analysis of cocaine trafficking in the Port of Rotterdam, Roks et al. (2021) show how organized crime groups make use of legal flows of goods to hide the contraband, with port companies and port employees sometimes knowingly and at other times unknowingly facilitating the trafficking of cocaine (cf. Madarie and Kruisbergen 2020). Therefore, in addition to the relational dimension, organized crime's structural and occupational dimensions also shed an important light on the role the social environment plays in the shielding of organized crime.

Taken together, this brief overview of the literature illustrates how the continuity and longevity of organized crime is not the result of isolation but rather the product of relational and structural embeddedness. Offenders deliberately conceal their criminal activities using opportunities provided by their social environment, including work settings (Kleemans and Van de Bunt 2008), services provided by professional intermediaries - such as lawyers or financial advisors (Lord et al 2019) —and other facilities in the regular, licit world. What follows from the social embeddedness of 
organized crime, as Van de Bunt's (2010) analysis of major frauds also illustrates, is that several parts of criminal activities cannot be hidden from the social environment. Victims, bystanders, and the broader local and social environment may be, to a certain extent, aware of ongoing criminal activities. This social environment can also function as an effective cover that contributes to the shielding and concealment of criminal activities or what Skinnari et al. (2019) describe as 'cultures of silence'.

In the remainder of this article, we will use the metaphor of 'walls of silence' to explore the ways the social environment contributes to the shielding of organized crime or criminal activities by organized crime groups in the Netherlands. In the following section, we elaborate on the methodological background of this study.

\section{Data and methods}

This article is based on empirical data collected during the fifth data sweep of the Dutch Organized Crime Monitor, an ongoing research project into the nature and development of organized crime in the Netherlands. Since the start of the first data sweep in 1996, 180 large-scale criminal investigations have been analyzed, containing the results of all policing activities, such as wiretapping, monitoring of internet traffic, undercover policing, interrogations of suspects, confiscation, and financial information (for more details, see Kleemans 2014; Kruisbergen et al. 2018; Leukfeldt et al. 2019: 331-333). The Dutch Organized Crime Monitor covers criminal investigations into criminal networks that have been completed by the police and have resulted in sufficient legal evidence for the Public Prosecution Service to decide to prosecute, and this means that the analysis is based on rather solid evidence (and fresh recollection of investigating officers), but that a final court judgment may not necessarily have been issued yet. For the purposes of the Dutch Organized Crime Monitor, this is the optimal trade-off between the solidity of evidence and topicality of cases (Kleemans 2014: 61-62). Waiting for a final court judgment would mean that it could take five to ten years for suspects to be finally convicted (after appeal). Therefore, we aim to analyze the cases at an earlier point in time. For the analysis of these criminal investigations, permission has been granted by the Netherlands Public Prosecution Service (see, for more details, Kleemans 2014).

For this paper, we used the 30 most recent cases based on criminal investigations completed between 2011 and 2016. These cases represent a variety of organized crime activities in the Netherlands, including various types of drug trafficking, arms trafficking, human trafficking, fraud and money laundering, and cybercrime (for more information, see Kruisbergen et al., 2018; 2019). The 30 cases for the fifth wave of data collection were selected after an intensive inventory of criminal investigations. This inventory took place through interviews with and visits to specialized units and various national and regional units within the police and Public Prosecution Service in the Netherlands. Discussions were held with specialists in the field of drugs (cocaine, heroin, synthetic drugs, and cannabis), cybercrime, fraud and money laundering, robberies, and human trafficking. This inventory was carried out for all ten regions of the police / Public Prosecution Service and a number of national units in the Netherlands. The inventory produced a 'long list' of about 70 cases, of which 
30 were eventually selected. Important criteria in the selection of the cases included heterogeneity in terms of criminal activities (as many investigations focus on drug trafficking and production), the presence of a criminal collaboration of multiple actors (see the prevailing organized crime definition discussed in the introduction), and 'richness of information' provided by special investigation methods used by the police (for more details, see Kruisbergen et al. 2018; 2019; Leukfeldt et al. 2019: 331-333).

Following an interview with a case officer or the team leader of the police, a checklist was used as an analytical framework to systematically analyze the 30 cases (for more details, see Kruisbergen et al. 2018). The themes of this checklist are roughly the same as during the first sweep of the Dutch Organized Crime Monitor (Kleemans et al. 1998), including information on criminal investigation and the special investigations methods that were used, the criminal network and the individual suspects, the criminal activities and modus operandi, relationships, the interconnectedness between offenders and their social environment, and criminal earnings. Each analysis results in an extensive case report that covers the main themes of the framework and that provides a summary of the underlying criminal investigation.

After familiarization with the empirical data from the case files, the first author started reviewing the data and assigning initial thematic codes in Atlas.ti 8 based on the literature on walls of silence and the social embeddedness of organized crime. After this first round of coding, the first author continued the analysis by an inductive open coding strategy, identifying the underlying and new themes in the data.

Criminal investigation files are the most important data source within the Dutch Organized Crime Monitor. The most fundamental limitation of this data source is that it is limited to persons and activities that came to the attention of the police and that were selected as targets of - successful—criminal investigations by law enforcement agencies. These selection effects are beyond the control of researchers and may lead to a bias in research findings. Criminal activities and offenders falling outside the scope and/or priorities of law enforcement agencies are also not available for analysis. However, this 'selective' view also entails an important advantage for gathering knowledge. As we will illustrate in the following section, anyone who wants to delve into criminal phenomena is confronted with the 'walls of silence' surrounding criminal activities, particularly when it comes to organized crime (Van de Bunt 2007; 2010; Kruisbergen 2017: 136-137). Only law enforcement agencies have farreaching powers to break through these 'walls' through the use of special investigation methods. Researchers having access to criminal investigation files benefit from these exclusive powers and can thus also gain an exclusive insight into the activities of offenders or how they relate to each other and their surroundings.

\section{Results}

In this section, we explore in which overarching ways the concealment and shielding of organized crime are apparent in the 30 cases. First, we describe how offenders deliberately try to shield their criminal activities by using the legal environment and the immediate social environment as a cover. Second, we zoom in on the ways the 
social environment is - to a certain degree-knowledgeable and plays a central part in shielding organized crime.

\section{How perpetrators use their environment for concealment: legality and familiarity}

\section{The legal environment}

In the cases we studied, we encounter various examples of offenders actively involving their (social) environment to conceal their criminal activities and this is apparent in the use of public places and semi-public locations, such as restaurants and shopping centers, as a meeting place. These legal environments have a certain degree of anonymity, partly because the chance of being overheard by law enforcement agencies is considered to be smaller. In our cases, we also see suspects who use their business premises to this end (cases $11,14,25$ ). In specific cases, such as case 25 , this takes on such proportions that it actually results in a criminal marketplace. The suspects in case 25 made use of a company building as a meeting point for buyers and sellers of a variety of drugs and raw materials for drug production. During the investigation period, multiple persons frequented the building on a daily basis, but the company declared no legal turnover during this time. Since the building was bugged, the police could overhear the visitors discussing the various technical aspects of the production of ecstasy and amphetamines (case 25).

Next to such criminal marketplaces, our cases also provide examples in which licit and illicit activities are more intertwined. In earlier reports, we focused, for instance, on employees of baggage handling companies at airports. For these suspects, the criminal activities were very much in line with their day-to-day activities: during the luggage transfers, it was hard to tell whether the employees were involved in regular or criminal activities (such as smuggling cocaine from airside to landside (import) or ecstasy from landside to airside (export) (Kruisbergen et al. 2012; Madarie and Kruisbergen 2020). Similar examples of illicit activities in line with licit activities involve money laundering practices and fraud by businessmen. The analyzed cases provide illustrations of entrepreneurs with licit businesses used for the laundering of criminal earnings (for example, cases 22 and 23), underground banking (case 27), or committing real estate and mortgage fraud (case 29).

Although it is not always possible to pinpoint when the suspects first got involved in criminal activities, the case files do provide insights into the factors contributing to the long-term concealment of these suspects. These factors concern, among others, the lack of a criminal record and occupations in which the criminal activities are an extension of licit activities. Because the criminal activities of the suspects in these cases are at the interface of organized crime and white-collar crime (Van de Bunt and Van Wingerde 2015), the occupations of these suspects provide an opportunity structure for organized crime and - simultaneously - add to the effective concealment of the criminal activities. Furthermore, these suspects also benefit from the trustworthiness and prestige that comes with their occupations, and that facilitates in staying out of the scope of law enforcement agencies (cf. Kleemans and Van de Bunt 2008; Van de Bunt et al. 2011). Lastly, not only do fraud and money 
laundering activities often rely on legal occupations and legal businesses (Kruisbergen et al. 2015), but this also applies to all kinds of trafficking activities, including drug trafficking (Madarie and Kruisbergen 2020; for a review, see Kleemans and Van Koppen 2020: 408-411).

\section{The immediate social environment: the family environment and beyond}

In the majority of the 30 cases, various people in the immediate social environment seemed to be (explicitly) aware of the (criminal) activities of the suspects, which raises the question: how can these suspects ensure that these bystanders remain silent, and that (incriminating) information does not reach law enforcement officials or malevolent competitors? In line with findings from previous studies (Kleemans et al. 1998: 42-44; Van de Bunt and Kleemans 2007: 49-56; Van Dijk et al 2021), we see that suspects navigate this challenge by seeking and finding their partners in crime and contacts close to home. In almost all the 30 cases we studied, we see that suspects operate from their immediate social environment, working with people they have known for a sustained period of time. In two cases, the criminal collaboration can even be described as a 'family business'. In case 16, for example, a 'mater familias' directs money couriers, with her husband, her son, and her daughter-inlaw performing activities that facilitate the transfer of cash money from Europe to Latin America. Another case (case 19) centers around a father and his son who are involved in the large-scale cultivation of cannabis. Two of the father's brothers and even the grandfather are involved in organizing and running various cannabis plantations in the region. Only two of the main suspects cannot be classified as blood relatives. However, one of them can also be considered 'family', since he is married to the sister of the main suspect.

In the cases in which the (main) suspects are not (immediate) family members, they appear to know each other very well, for example, because they have been friends for a long time. Case 17 offers a good illustration: a small, close-knit group of friends have been involved in the international cocaine trade for years. One of the main suspects in another case explicitly expresses his desire for a close circle of confidants when he indicates that "he has his own club with B. and that crazy C. and D. and that they have such a good team. A. wants to keep it nice and relaxed and small" (one of the studied cases). This case-as well as similar cases - reveals the strength of strong social ties, as is also documented in other studies on trust in organized crime (Kleemans and Van de Bunt 1999; Von Lampe and Johansen 2004): a limited core of confidants is used as a response to the dormant mistrust that haunts organized crime. In general, however, criminal investigations do not always provide insight into the precise origins of these social relationships, apart from sporadic examples from overheard conversations or police interrogations. Suspects have sometimes grown up together, got to know each other on the job, in prison, or through shared membership of an outlaw motorcycle gang.

Operating from a well-known social environment can be viewed as an answer to trust problems, but it is not a panacea. Our cases also contain signs of distrust amongst family and friends. Case 17 , for instance, documents a heated discussion between the main suspects about information that fell into the hands of the police, 
which fuels suspicion within the group. The main suspect states: "We have been friends for all these years, I am constantly sticking my neck out for you, I do everything for you, everything in our power. I should be able to trust you, you know" (one of the studied cases). Because the suspects have known each other for quite some time, the distrust is addressed immediately in order to find a solution for the problem at hand.

\section{Walls of silence: ignorance, benefit, and fear}

In the cases we examined, we find three additional mechanisms underlying silence, although people are - or should be - aware of criminal activities (Skinnari et al. 2019). In the remainder of this section, we describe the shielding of organized crime by exploring the ignorant, the benefiting, and the fearful environment. We discuss these walls of silence as separate environments, but in practice, these reasons to 'hear, see, and remain silent' may be operating simultaneously.

\section{The ignorant environment}

Ignorance may provide a general explanation for bystanders remaining silent: it may be the case that the social environment is not fully aware of criminal activities or does not want to be aware. In the 30 cases we studied, we found various examples of people apparently not being fully conscious of the criminal activities taking place. This often concerns aspects of the logistical process of criminal activities, such as entrepreneurs who have rented out - in good faith-buildings or warehouses used as a cannabis plantation, a lab to produce synthetic drugs or a narcotics stash. In addition, we also came across logistic and transport companies (such as shipping companies and container terminals) or truck drivers who unwittingly enable the import or export of drugs (cf. Kruisbergen et al. 2012; Staring et al. 2019; Roks et al. 2021).

However, based on the case files and the additional interviews with team leaders at the police or public prosecutors, it is by no means always possible to ascertain to what extent bystanders are unaware of the criminal activities or whether suspects, witnesses, and other parties involved are only (successfully) pretending to be ignorant. For instance, in one case, more than a few million euros in cash was found in the attic room of a main suspect's parents. During the police interrogations, they defended themselves by stating that they would never enter the attic themselves. At the same time, they indicated that they did not find it strange that their son regularly came to their attic to bring or get something. This example illustrates how the social environment purposely seems to look away to remain ignorant.

The parents in the abovementioned example were not regarded as suspects in the case. In some of the other cases we studied, these bystanders were prosecuted. The documentation of the police interrogations, however, shows a similar pattern of suspects stating that they did not know how it was possible that (substantial) amounts of narcotics, cash or firearms were found in their homes or business premises. In many of the cases we studied, we can observe ignorance that lies in the gray area between knowing and not knowing (Van de Bunt 2007: 120-121). A suspect in one 
of the cases expressed this as follows: "I never asked where the money came from. I didn't want to know this. The less I know, the better it is for me. I know there are risks" (one of the studied cases). The statement of money mules in a different case is quite similar, proclaiming that they were uninformed of the amount they were smuggling across national borders or even that they were completely unaware that their suitcase contained a substantial amount of money (case 16). With such statements, suspects protect not only themselves but also the broader criminal collaboration and, thereby, construct a wall of silence.

In these last cases, however, it is difficult to maintain that the suspects are actually ignorant. These statements, like many other cases in which bystanders indicate that they are unaware of the criminal activities, can be interpreted as examples of concerted ignorance (Katz 1979). After all, suspects but also witnesses and others involved must have an alibi when criminal activities come to light and this is especially the case when they have played a facilitating or supporting role in the commission or shielding of criminal activities.

Ignorance can also be a deliberate part of the modus operandi of a criminal collaboration (cf. Gambetta 2009: 61). In some of the cases we studied, the core suspects are fully aware of the ins and outs of specific criminal endeavors, but this is not the case for suspects in the periphery who only have an executive role. In one of the cases we analyzed, the main suspect only reaches out to a fixed group of confidants and never gets his hands dirty himself. If the criminal activities result in an arrest, it is difficult to trace these activities back to the organizing forces of the criminal association.

\section{The benefiting environment}

Emphasizing ignorance towards the police-or being silent in general—can also be motivated by the fact that several parties, such as co-offenders, facilitators, and others in the immediate vicinity, benefit from the concealment of criminal activities. Money seems to be an important reason why the social environment remains silent in this respect. In one of the cases we studied, the girlfriend of the main suspect - who is aware of the ways he makes his money - is showered with gifts, such as expensive jewelry, clothing, and luxurious holidays. Having access to large amounts of cash money or luxury goods seems to be an important reason why some parents, wives, and girlfriends, or children do not question the origin of the money. In some cases, money is used to keep people loyal or to (temporarily) buy their silence. For example, when in one case a suspect is arrested abroad, the other suspects pay the substantial lawyer fees and financially support the immediate family members of the arrested suspect for some time.

Our cases also contain examples of situations in which several parties - often facilitators of various types of organized crime-seem to benefit from the prolonged secrecy of criminal activities. In a case about the physical transport of cash money from Europe to Latin America (case 16), one of the main suspects booked the trips for the money mules, mostly prostitutes or women from the same country as the main suspects. In this case - and in another case in which offenders travel the globe regularly - travel agencies play an important (un)conscious role. Case 16 shows how 
the trips are booked at three different travel agencies and paid in cash. Moreover, several flights are booked by the same people in a relatively short amount of time. Although the criminal investigation by the police was unable to conclude that the travel agencies, or their employees, were aware of the money transports, the fact that the same people booked a lot of flights and always paid in cash should have raised some red flags.

In a different case featuring a travel agency, this issue was raised during a police interrogation. The employee of the travel agency declared that he thought these practices were "not kosher", but that he also found it difficult to draw the fine line between remarkable and suspicious. In this case, the total sum of the bookings was almost $€ 200.000$, all paid in cash. The investigation revealed that the employee of the travel agency received a fixed amount of brokerage costs per transaction (one of the studied cases). In other cases, we also come across examples in which those involved benefit from the continuation of the (criminal) activities, and this was particularly evident in a case regarding a corrupt customs officer. During interrogation, he declared that he received a fixed percentage of the proceeds of every container that he kept out of the inspection, for instance, by changing the container's status in the customs systems (case 13).

\section{The fearful environment}

The preceding section indicates that it is important to distinguish between people from the social environment who have an interest in the continuation of criminal activities on the one hand and the continuation of secrecy on the other (Van de Bunt 2007: 124). After all, bystanders may contribute to the shielding of organized crime, even if they do not benefit directly from the criminal activities, and this is especially the case when it comes to the negative consequences of the disclosure of criminal activities. Intimidation, violent threats, or the actual use of violence can be used by organized crime groups to ensure silence and to prevent people from disclosing information to law enforcement agencies (Zaitch 2005; Kruisbergen et al 2012, 74-75; Hofmann \& Gallupe 2015: 132-133; Skinnari et al. 2019). After all, a fearful environment is often a quiet environment.

The role of fear could be observed, among other things, in the defendants' attitude during the trial. Similar to a previous report of the Dutch Organized Crime Monitor (Van de Bunt and Kleemans 2007: 148-149), we come across examples of suspects or witnesses who remain silent because they have concerns about the possible consequences of speaking up. As one of the analyzed cases illustrates, their concern is not always about their own safety but primarily about the safety of their loved ones, or as a suspect stated: "I'm not that afraid of my own safety, but I am worried about my wife and children" (one of the studied cases). In general, the threat of violence against loved ones seems to be an important reason why suspects or witnesses invoke their right to remain silent during police interrogations. This fear, at times, is the direct result of specific threats, whereas in other cases, the threats of violence can be read between the lines and are the product of the violent reputation of certain (main) suspects, and this is illustrated in the following statement from one of the cases we studied: "Because he is a former forensic psychiatric patient, I don't want 
him to hurt my family. I don't want my parents to have to sleep with one eye open" (one of the studied cases).

Although fear can often be traced back to (threats of) violence, there are also examples, in many cases we studied, in which the negative consequences of disclosure take a different form. We can observe this in circumstances in which people are dependent on the (main) suspects. For instance, in a criminal investigation into human trafficking, sailors from the Philippines had to work long hours, exceeding their 40-h working week contracts. Some sailors complained about their working conditions and also sometimes about the lack of sufficient food on board and having to continue working in the event of illness. However, the terms and conditions in their contracts stated that if they wanted to return to the Philippines prematurely, they would bear the costs of the return flight but also the costs of the sailor to replace them. The sailors also had to hand in their workbooks when they went on leave. If they refused, they would not receive any leave pay and often not their last monthly salary. Switching to another employer was also seriously complicated because of these financial penalties and because the sailors needed their workbooks to show their work experience, which was relevant to their salary level (case 10). In this case, enduring these circumstances seems to be prompted by fear of disclosure rather than the threat of physical violence.

Although fear can be a powerful way to prevent disclosure, the use of (threats of) violence also has a serious downside. After all, too much violence not only attracts the attention of law enforcement agencies but can also deter potential business partners and, moreover, hinder the relationship with the social environment (Zaitch 2005: 205-206), and this is highlighted in one of the cases showing how intimidation and violent threats make a suspect go to the police because he fears for his own and his family's lives In an extraordinarily detailed manner, he ends up reporting on the composition of the criminal network, their modus operandi, and criminal earnings. His testimonies form the base of the criminal cases against the main suspects (case 19).

\section{A framework for the shielding of organized crime activities: conclusions and policy implications}

In this article, we focused on the shielding of organized crime in 30 large-scale police investigations into organized crime in the Netherlands. We departed from Van de Bunt's (2007; 2010) metaphor of 'walls of silence' and applied this perspective to explore the role of the social environment in the shielding of organized crime. Our results indicate that, in accordance with Van de Bunt's $(2007$; 2010) analysis of major fraud cases, concealment is not the product of total isolation or absolute secrecy. Rather, this article illustrates that organized crime can grow, endure, and sometimes even prosper without being caught by law enforcement authorities because the social environment operates as walls of silence.

Our findings show that the shielding and concealment of organized crime by the social environment can take place in two overarching ways. First, we discussed examples of how offenders shield their (criminal) activities by using the possibilities 
offered by the legal environment. These examples show how structural and occupational embeddedness are beneficial to raising walls of silence that are not easily penetrated by law enforcement agencies (Van de Bunt et al. 2014). Second, we came across cases in which offenders were unable to completely hide their (criminal) activities from the social environment. In these cases, various bystanders were, to varying degrees, aware of the criminal activities and had a more active, facilitating role in shielding these criminal activities, which highlights the importance of relational aspects of embeddedness in organized crime (Kleemans and Van de Bunt 1999; Kleemans and De Poot 2008; Kleemans and Van Koppen 2020). We also discussed how ignorance, benefit, and fear function as mechanisms underlying silence (Skinnari et al. 2019) and ensure that the social environment, which in many cases seems to be aware of the (criminal) activities of offenders, shrouds in silence.

Figure 1 provides an overview of a framework that follows from the theoretical and empirical exploration in this article. In Fig. 1, the offender is center stage, surrounded by environments that can play a facilitating or supporting role in different ways: by committing criminal activities or contributing substantially to the (longterm) shielding of offenders and their criminal acts. The size of these circles varies per perpetrator, but also per specific type of criminal activity. Some perpetrators operate as 'local heroes' (Kleemans et al. 2002: 74-75) from their immediate social environment, with various family members and friends being aware of the criminal activities being perpetrated. Other offenders are surrounded by a limited group of confidants. Ongoing criminal activities are also often visible to the immediate family environment, and this immediate environment can act as an important social 'cover' in this context. Beyond this family ring, other rings refer to the ignorant, benefiting and/or frightened environment and the legal environment, which are

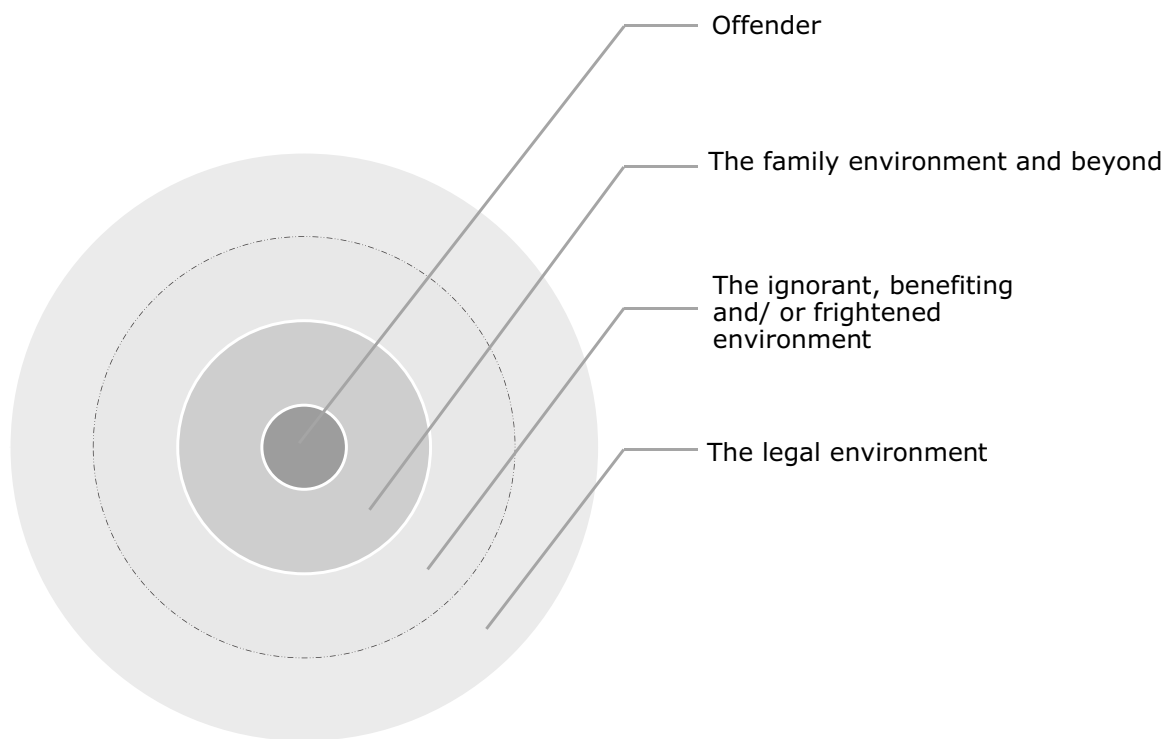

Fig. 1 Framework of the social embeddedness of organized crime 
separated by a dotted line in this figure. This dotted line indicates that the size of these circles may vary - for instance for different forms of crime-and can be influenced. From the offender's perspective, these circles can be larger or smaller. An offender who is successful as a criminal and protects his or her criminal activities can increase the size of the circle, thereby involving an ever-greater proportion of the social environment in these criminal activities or the protection thereof through ignorance, economic gain, or fear.

However, the central idea behind Fig. 1 is that the size of the circle is determined not only by the offender, but also by actors in the immediate social environment, the police, the criminal justice system, policymakers, and local administrations. Legislation and regulations determine the legal scope within which citizens, offenders, and law enforcement agencies can operate. Still, they also have an impact on the ignorant, benefiting, and/or fearful environment. The emphasis could be placed on how offenders can go about their business relatively undisturbed and how this free space around offenders and their immediate social environment could be restricted by making it more difficult to operate legitimately or by making the social environment more resilient by addressing the factors of ignorance, economic gain, and fear. After all, the immediate social environment can contribute to or protect criminal activities for all manner of reasons. Still, it could also play a key role in preventing or combating these criminal activities. This counterforce in the environment, its resilience, can, in turn, be promoted through government action.

Based on our findings, the following potential policy implications could be formulated. First, through specific awareness campaigns, one might alert individuals within the environment - ranging from residents to civil servants-and motivate them to use their eyes and ears to prevent or report specific criminal activities, such as the criminal use of licit structures. Second, there are actors who play a more active role and who, to a greater or lesser extent, wittingly or unwittingly, facilitate the activities of criminal groups: for example, providers of financial and legal services, such as advisers, trust offices, and lawyers; or suppliers of expensive goods and services who sell or rent out cars, scooters, boats, electronics, and houses in return for cash payments. Regulations can be used as a tool for countering ignorance (feigned or otherwise), removing excuses (Cornish and Clarke 2003; Soudijn 2011), and reducing the benefits that facilitation of organized crime brings for some individuals. Finally, our findings indicate that fear can be a key factor in keeping offenders off the radar. User-friendly, anonymous ways of sharing information with the police and the judiciary may be a way to overcome fear and make people more inclined to report crimes.

The results from the 30 large-scale police investigations into organized crime in the Netherlands in this article show that organized crime's walls of silence are by no means infallible. Although special investigation methods by law enforcement agencies in these cases provide an exclusive insight into organized crime and how the social environment added to the shielding of these activities, it also highlights the limitations of the current study. In this article, we focused on cases prioritized by the Dutch police and in which offenders were caught and prosecuted. Moreover, not all cases contained the same amount of information on the role of the social environment in the concealment of the criminal activities of the offenders. For a better 
understanding of the mechanisms underlying silence in organized crime, future research could try to shed light on the perspectives and experiences of the people who are part of these walls of silence surrounding organized crime: co-offenders, facilitators, victims, and bystanders who play a pivotal role in the shielding and concealment of organized crime.

Open Access This article is licensed under a Creative Commons Attribution 4.0 International License, which permits use, sharing, adaptation, distribution and reproduction in any medium or format, as long as you give appropriate credit to the original author(s) and the source, provide a link to the Creative Commons licence, and indicate if changes were made. The images or other third party material in this article are included in the article's Creative Commons licence, unless indicated otherwise in a credit line to the material. If material is not included in the article's Creative Commons licence and your intended use is not permitted by statutory regulation or exceeds the permitted use, you will need to obtain permission directly from the copyright holder. To view a copy of this licence, visit http://creativecommons.org/licen ses/by/4.0/.

\section{References}

Bouchard M, Morselli C (2014) Opportunistic Structures of Organized Crime. In: Paoli L (ed) The Oxford Handbook of Organized Crime. Oxford University Press, Oxford, pp 288-302

Bouchard M (2020) Collaboration and Boundaries in Organized Crime: A Network Perspective. Crime and Justice. A Revies of Research 49:425-469

Bright D, Whelan C (2020) Organised Crime and Law Enforcement. A Network Perspective. Routledge, Lodon

Bunt, HG van de (2007). Muren van stilzwijgen. In: Bunt, HG van de, Spierenburg, P \& R van Swaaningen (eds.), Drie perspectieven op sociale controle (pp. 113- 136). Den Haag: Boom Juridische Uitgevers.

van de Bunt HG (2010) Walls of secrecy and silence: The Madoff case and cartels in the construction industry. Criminol Public Policy 9(3):435-453

Bunt, HG van de, Kleemans, ER, in conjunction with Poot, CJ de, Bokhorst, RJ, Huikeshoven, M, Kouwenberg, RF, Nassou, M van, \& Staring, R (2007). Georganiseerde criminaliteit in Nederland: Derde rapportage op basis van de Monitor Georganiseerde Criminaliteit [Organized crime in the Netherlands. Report in the context of the third round of the Organized Crime Monitor]. Den Haag: Boom Juridische uitgevers.

van de Bunt HG, Siegel D, Zaitch D (2014) The social embeddedness of organized crime. In: Paoli L (ed) The Oxford Handbook of Organized Crime. Oxford University Press, Oxford, pp 321-339

Bunt, HG van de, Wingerde, CG van (2015). We are all going to be rich: A case study of the Dutch real estate fraud. In: Huisman, W Erp, JG van \& Vande Walle G (eds.) Routledge Handbook of WhiteCollar and Corporate Crime in Europe (pp. 304-317). Oxford: Routledge.

Burt RS (1992) Structural Holes. Harvard University Press, Cambridge, MA

Campana P (2011) Eavesdropping on the Mob: The Functional Diversification of Mafia Activities across Territories. Eur J Criminol 8(3):213-228

Carrington, P (2011). Crime and Social Network Analysis. In: Scott, J., Carrington, PJ (eds) Sage Handbook of Social Network Analysis. London: Sage.

Catino M (2020) Italian Organized Crime since 1950. Crime and Justice. A Revies of Research 49:69-140

Cornish DB, Clarke RV (2003) Opportunities, precipitators and criminal decisions: A reply to Wortley's critique of situational crime prevention. Crime Prevention Studies 16:41-96

Fielding NG (2017) The shaping of covert social networks: isolating the effects of secrecy. Trends in Organized Crime 20(1):16-30

Fijnaut C, Paoli L (2004) Organised crime in Europe: Concepts, patterns and control policies in the European Union and beyond. Springer, Dordrecht 
Fijnaut, C, Bovenkerk, F, Bruinsma, G, van de Bunt, HG (1998). Organized crime in the Netherlands. The Hague/ London/ Boston: Kluwer Law International.

Gambetta D (2009) Codes of the underworld: How criminals communicate. Princeton University Press, Princeton, NJ

Granovetter M (1985) Economic action and social structure: the problem of embeddedness. Am J Sociol 91(3):481-510

Hofmann DC, Gallupe O (2015) Leadership protection in drug-trafficking networks. Global Crime 16(2):123-138

Jaspers JD (2020) Strong by concealment? How secrecy, trust, and social embeddedness facilitate corporate crime. Crime Law Soc Chang 73(1):55-72

Katz J (1979) Concerted ignorance: The social construction of cover-up. Urban Life 8(3):295-316

Kleemans ER (2007) Organized crime, transit crime, and racketeering. Crime Justice 35(1):163-215

Kleemans, ER (2014). Organized Crime Research: Challenging Assumptions and Informing Policy. In Cockbain, E, Knutsson, J (eds.) Applied Police Research: Challenges and Opportunities. London: Routledge.

Kleemans ER, van de Bunt HG (2008) Organised crime, occupations and opportunity. Global Crime 9:185-197

Kleemans, ER, Van Koppen MV (2020). Organized crime and criminal careers. Crime and Justice. A Review of Research 49: 385-423

Kleemans, ER, Berg, EAIM van den, Bunt, HG van de, in conjunction with Brouwers, M, Kouwenberg, RF, Paulides, G (1998). Georganiseerde criminaliteit in Nederland: Rapportage op basis van de WODC-monitor [Organized crime in the Netherlands: Report based on the Research and Documentation Centre Monitor]. The Hague: WODC (Research and Documentation Centre).

Kleemans, ER, Brienen, MEI, Bunt, HG van de, in conjunction with Kouwenberg, RF, Paulides, G, Barensen, J (2002). Georganiseerde criminaliteit in Nederland: Tweede rapportage op basis van de WODC-monitor [Organized crime in the Netherlands: Second report based on the Research and Documentation Centre Monitor]. The Hague: WODC (Research and Documentation Centre).

Kleemans ER, van de Bunt HG (1999) The Social Embeddedness of Organized Crime. Transnational Organized Crime 5(1):19-36

Kleemans ER, de Poot CJ (2008) Criminal careers in organized crime and social opportunity structure. Eur J Criminol 5(1):69-98

Krebs, VE (2002) Mapping networks of terrorist cells. Connections 24: 43-52

Kruisbergen EW (2017) Combating Organized Crime: A Study on Undercover Policing and the FollowThe-Money Strategy. PhD diss. Vrije Universiteit, Amsterdam

Kruisbergen, EW, Bunt, HG van de, Kleemans, ER (2012). Georganiseerde criminaliteit in Nederland. Vierde rapportage op basis van de Monitor Georganiseerde Criminaliteit [Organized crime in the Netherlands: Fourth report based on the Organized Crime Monitor]. The Hague: Boom Lemma.

Kruisbergen EW, Kleemans ER, Kouwenberg RF (2015) Profitability, Power, or Proximity? Organized Crime Offenders Investing Their Money in Legal Economy. Eur J Crim Policy Res 21(2):237-256. https://doi.org/10.1007/s10610-014-9263-5

Kruisbergen, EW, Leukfeldt, ER, Kleemans, ER, Roks, RA (2018). Georganiseerde criminaliteit en ICT. Rapportage in het kader van de vijfde ronde van de Monitor Georganiseerde Criminaliteit [Organized crime and IT. Report in the context of the fifth round of the Organized Crime Monitor]. The Hague: WODC (Research and Documentation Centre).

Kruisbergen EW, Leukfeldt ER, Kleemans ER, Roks RA (2019) Money talks: Money Laundering Choices of Organized Crime Offenders in a Digital Age. Journal of Crime and Justice. https://doi. org/10.1080/0735648X.2019.1692420

Leukfeldt, ER, Kleemans, ER, Stol, WP (2017). Origin, growth and criminal capabilities of cybercriminal networks. An international empirical analysis. Crime, Law and Social Change, 67(1): 39-53.

Leukfeldt ER, Kleemans ER, Kruisbergen EW, Roks RA (2019) Criminal networks in a digitised world: on the nexus of borderless opportunities and local embeddedness. Trends in Organized Crime 22(3):324-345

Lord NJ, Campbell LJ, Van Wingerde K (2019) Other people's dirty money: professional intermediaries, market dynamics and the finances of white-collar, corporate and organized crimes. Br J Criminol 59(5):1217-1236

Madarie, R, \& Kruisbergen, EW (2020). Traffickers in transit: Analysing the logistics and involvement mechanisms of organized crime at logistical nodes in the Netherlands. Empirical results of the 
Dutch Organized Crime Monitor. In Weisburd D, Savona EU, Hasisi Band Calderoni F (eds) Understanding Recruitment to Organized Crime and Terrorism. New York: Springer.

Morselli C (2009) Inside Criminal Networks. Springer, New York

Morselli C, Giguère C, Petit K (2007) The efficiency/security trade-off in criminal networks. Social Networks 29(1):143-153

Natarajan M (2006) Understanding the Structure of a Large Heroin Distribution Network: A Quantitative Analysis of Qualitative Data. J Quant Criminol 22(2):171-192

Paoli, L, Vander Beken, T (2014). Organized crime: A contested concept. In L. Paoli (Ed.), The Oxford Handbook of Organized Crime. New York: Oxford University Press

Paoli L (2003) Mafia Brotherhoods: Organized Crime, Italian Style. Oxford University Press, New York

Paoli L (2020) What Makes Mafias Different? Crime and Justice. A Revies of Research 49:141-222

Reuter P, Paoli L (2020) How Similar Are Modern Criminal Syndicates to Traditional Mafias? Crime and Justice. A Revies of Research 49:223-287

Roks, RA, Bisschop, LCJ, Staring, RJHM (2021). Getting a foot in the door. Spaces of cocaine trafficking in the Port of Rotterdam. Trends in Organized Crime, (2021) 24:171-188

Savona, EU, Calderoni, F, Superchi, E, Comunale T, Campedelli, GM, Marchesi, M, Kamprad, A (2017) Systematic Review on the Social, Psychological and Economic Factors relating to Criminalization and Recruitment to organized crime. Milan: UCSC-Transcrime. https://www.projectproton.eu/wpcontent/uploads/2018/01/D1.1-Report-on-factors-relating-to-organized crime.pdf

Siegel D (2011) Secrecy, betrayal and crime. Utrecht Law Review 7(3):107-119

Skinnari, J, Jonsson, A, Vesterhav, D (2019). Cultures of silence. A study of silence towards the criminal justice system. English summary of Brå report 2019:10. Stockholm, Sweden: The Swedish National Council for Crime Prevention (Brå).

Soudijn MRJ (2011) Geen smoesjes meer: De strategie van 'removing excuses' toegepast op financiële facilitators. Justitiële Verkenningen 37(2):40-57

Staring, RJHM, Bisschop, LCJ, Roks, RA, Brein, E., Bunt, HG van de (2019). Drugscriminaliteit in de Rotterdamse haven: aard en aanpak van het fenomeen [Drug-related crimes in the Port of Rotterdam: Nature of and approach to the phenomenon]. Den Haag: Boom Criminologie

Van Koppen, MV, Geest, VR van der, Kleemans, ER, Kruisbergen, EW (2020). Employment and Crime: A Longitudinal Follow-up of Organized Crime Offenders. European Journal of Criminology (First published: July 29, 2020) https://doi.org/10.1177/1477370820941287

Varese F (2011) Mafias on the Move. Princeton University Press, Princeton, NJ / Oxford

Varese, F (2020). How Mafias Migrate: Transplantation, Functional Diversification, and Separation. Crime and Justice. A Revies of Research 49: 289-337

Van Dijk M, Eichelsheim V, Kleemans E, Soudijn M, Van de Weijer S (2021) Intergenerational continuity of crime among children of organized crime offenders in the Netherlands. Crime Law Soc Chang. https://doi.org/10.1007/s10611-021-09970-1

Von Lampe K, Johansen PO (2004) Organized crime and trust: on the conceptualization and empirical relevance of trust in the context of criminal networks. Global Crime 6(2):159-184

Zaitch D (2005) The ambiguity of violence, secrecy, and trust among Colombian drug entrepreneurs. Journal of Drug Issues 35(1):201-228

Publisher's note Springer Nature remains neutral with regard to jurisdictional claims in published maps and institutional affiliations. 